\title{
Reconstruction of extensive scalp defects with anterolateral thigh flap
}

\author{
๑ Altuğ Altınkaya, M.D., ${ }^{1}$ Şükrü Yazar, M.D., ${ }^{1} @$ İbrahim Sağlam, M.D., ${ }^{2} @$ Kaan Gideroğlu, M.D. ${ }^{3}$
}

${ }^{1}$ Department of Plastic, Reconstructive and Aesthetic Surgery, Acıbadem Mehmet Ali Aydınlar University, Acıbadem Maslak Hospital, İstanbul-Turkey 2Department of Plastic, Reconstructive and Aesthetic Surgery, Harran University, Training and Research Hospital, Şanlıurfa-Turkey

${ }^{3}$ Department of Plastic, Reconstructive and Aesthetic Surgery, Kartal Dr. Lütfi Kırdar Training and Research Hospital, İstanbul-Turkey

\begin{abstract}
BACKGROUND: Extensive scalp defects caused by various etiologies often require free-tissue transfer. We aimed to review our experience in the reconstruction of extensive scalp defects with free anterolateral flaps.
\end{abstract}

METHODS: A retrospective analysis was performed on all patients with extensive scalp defects that were reconstructed with free anterolateral thigh flaps from November 2007 to April 2015. Eleven patients with a mean age of 44 years were included in this study.

RESULTS: Eleven free-tissue transfers were used to reconstruct the extensive scalp defects. The flaps were 7-14 cm in width and $10-34 \mathrm{~cm}$ in length.

CONCLUSION: Microvascular free-tissue transfer is the mainstay for the treatment of extensive scalp defects. We recommend anterolateral thigh free flap use for challenging and complex cases, given the method's numerous advantages, including reliability and safety.

Keywords: Anterolateral thigh flap; free flap; scalp.

\section{INTRODUCTION}

Scalp defects can occur secondary to traumatic injuries, infections, irradiation, or oncological resections. ${ }^{[I]}$ However, there are many options for scalp reconstruction. For small defects, primary closure is the recommended approach. When primary closure is not attainable, skin grafting, tissue expansion, and the use of local or regional tissue flaps can be used as alternative methods.

The use of free flaps is the only treatment option for large scalp defects with associated impaired viability of the surrounding tissue such as heavy trauma, osteoradionecrosis, osteomyelitis, and previous local flap failure. ${ }^{[2]}$ Numerous free flap sources have been described in the literature for scalp re- construction, including the latissimus dorsi, rectus abdominis, serratus anterior, omentum, radial forearm, and anterolateral free flaps. ${ }^{[3]}$ Each of these sources has advantages and disadvantages.

Omentum was the first free flap described in scalp reconstruction. ${ }^{[4]}$ Its large surface area provides an advantage in the reconstruction of wide scalp defects. However, the laparotomy requirements for harvesting and secondary complications thereafter, such as adhesions, ileus, and ventral hernia, limit its usage. ${ }^{[5]}$

The latissimus dorsi muscle can serve as a musculocutaneous or muscular flap in scalp reconstruction, given its large surface area and long vascular pedicle. ${ }^{[6,7]}$ However, it has certain

Cite this article as: Altınkaya A, Yazar Ş, Sağlam İ, Gideroğlu K. Reconstruction of extensive scalp defects with anterolateral thigh flap. Ulus Travma Acil Cerrahi Derg 2018;24:364-368.

Address for correspondence: Altuğ Altınkaya, M.D.

Acıbadem Maslak Hastanesi, Plastik, Rekonstrüktif ve Estetik Cerrahi Anabilim Dalı, İstanbul, Turkey

Tel: +90 212 - 3042143 E-mail: altugaltinkaya@yahoo.com 
disadvantages that include the requirement of repositioning the patient intraoperatively to harvest the flap, an unnatural appearance of a skin island in the scalp, difficulty in clinical flap monitoring particularly for the muscle-only flaps, a lack of durability in split-thickness grafts, potential complications such as seroma and wound dehiscence in the donor area, and, finally, sacrification of a functional muscle. ${ }^{[8]}$

The serratus anterior flap is another option for scalp reconstruction. The main limitation of this flap is its size. The combined use of the latissimus dorsi and serratus anterior flap has been reported for larger defects. ${ }^{[9-1 !]}$ It is possible to transfer vascularized ribs with serratus anterior muscle as a composite flap, which is a useful option in the simultaneous reconstruction of soft tissue and cranium. ${ }^{[I]}$

The rectus abdominis muscle or musculocutaneous flap can be used in medium-sized scalp defects. The musculocutaneous flap has a very thick skin island, and abdominal skin does not have adequate color harmony with scalp skin. ${ }^{[12,13]}$ Complications such as weakness or a hernia in the abdominal wall have been reported with the use of this flap. ${ }^{[14]}$

The radial forearm flap has thin, pliable skin and usually is a suitable option for scalp reconstruction. The major concerns regarding this flap involve sacrificing a major artery as well as donor area morbidity and size limitations. ${ }^{[15]}$

The most suitable option for the reconstruction of extensive scalp defects is the anterolateral thigh free flap. The tissue can be harvested in large sizes, provides durable soft tissue, and allows single-stage reconstruction of the defect. Further, the donor area is in an aesthetically desirable region that can be easily hidden with clothing. ${ }^{[16,17]}$
This case series outlines our experiences using anterolateral thigh free flaps in extremely large or near-total scalp defects and discusses the advantages and disadvantages of this surgical approach.

\section{MATERIALS AND METHODS}

We included II patients, and informed consent was obtained from all. All procedures performed in this study were in accordance with the ethical standards of the institutional national research committee and with the 1964 Helsinki Declaration and its later amendments or comparable ethical standards. Acıbadem Mehmet Ali Aydınlar University institutional review board approved this study protocol. The study period ranged from November 2007 to April 2015. All patients were treated with anterolateral thigh flaps for scalp reconstruction; patient data are summarized in Table I. The patients' ages ranged from 23 to 65 years; six patients were male and five were female. Malignant tumors (nine of II), radionecrosis (one of $\mathrm{II}$ ), and an unstable scar (one of $\mathrm{II}$ ) comprised the defect etiologies of our study. The histologic diagnoses of the malignant tumors were malignant melanoma (four patients), malignant proliferating trichilemmal tumor (two patients), squamous cell carcinoma (two patients), and dermatofibrosarcoma protuberans (one patient).

The sizes of the flaps were $10-34 \mathrm{~cm}$ in length and 7-17 cm in width. In five patients, the flap vessels were anastomosed to the superior thyroid artery and a branch of the internal jugular vein; superficial temporal vessels were used in four patients and facial vessels in two.

\section{RESULTS}

Eleven anterolateral thigh flaps were harvested. The donor

Table I. A summary of patients' data, including etiology, defect size, recipient vessel, and complications

\begin{tabular}{|c|c|c|c|c|c|c|c|c|}
\hline $\begin{array}{l}\text { Patıent } \\
\text { No. }\end{array}$ & Gender & Age & Etiology & $\begin{array}{l}\text { Defect } \\
\text { size }\end{array}$ & $\begin{array}{l}\text { Recipient } \\
\text { vessel }\end{array}$ & $\begin{array}{l}\text { Donor site } \\
\text { repair }\end{array}$ & Complication & Follow up \\
\hline I & Male & 23 & Squamous cell carcinoma & $7 \times 13$ & STA & Primary closure & None & Unremarkable \\
\hline 2 & Female & 51 & Malignant melanoma & $8 \times 14$ & FA & Primary closure & None & Unremarkable \\
\hline 3 & Female & 56 & $\begin{array}{l}\text { Malignant proliferating } \\
\text { trichilemmal tumor }\end{array}$ & $12 \times 18$ & SThA & Skin graft & None & Unremarkable \\
\hline 4 & Male & 47 & Squamous cell carcinoma & $12 \times 18$ & SThA & Skin graft & None & Unremarkable \\
\hline 5 & Female & 62 & Malignant melanoma & $12 \times 23$ & STA & Primary closure & None & Unremarkable \\
\hline 6 & Male & 39 & Radionecrosis & $6 \times 16$ & STA & Primary closure & Hematoma & Unremarkable \\
\hline 7 & Male & 37 & Malignant melanoma & $6 \times 12$ & SThA & Primary closure & None & Unremarkable \\
\hline 8 & Male & 45 & $\begin{array}{c}\text { Dermatofibrosarcoma } \\
\text { protuberans }\end{array}$ & $9 \times 13$ & STA & Primary closure & None & Unremarkable \\
\hline 9 & Female & 24 & Malignant melanoma & $5 \times 13$ & SThA & Primary closure & None & Unremarkable \\
\hline 10 & Male & 65 & $\begin{array}{l}\text { Malignant poliferating } \\
\text { trichilemmal tumor }\end{array}$ & $15 \times 32$ & SThA & Skin graft & None & Ex \\
\hline II & Female & 39 & Unstable Scar & $8 \times 10$ & FA & Primary closure & Haematoma & Ex \\
\hline
\end{tabular}

STA: Superficial temporal artery; FA: Facial artery; SThA: Superior thyroid artery. 
site was closed primarily in eight patients, whereas splitthickness skin grafting was necessary for three patients. Two patients had donor site hematomas on the second day; the hematomas were evacuated, and donor sites were closed primarily in the operating room. All flaps remained viable without complication. The mean follow-up was 36 months. During the study period, one patient died because of local recurrence of a malignant proliferating trichilemmal tumor, and another patient died due to myocardial infarction in the early follow-up period. Table I summarizes the surgical and follow-up data.

\section{Case 1}

A 65-year-old male patient was referred to our clinic. He presented with a rapidly growing ulcerated mass in the scalp. An excision with 2-cm intact skin margins was performed, and the defect was closed with skin graft. The pathological finding was malignant proliferating trichilemmal tumor. In 3 weeks, he had local recurrence (Fig. Ia), and radical resection of the tumor and bilateral neck dissection were performed. The resultant scalp defect was $15 \times 32 \mathrm{~cm}$ (Fig. Ib). An anterolateral thigh flap of $17 \times 34 \mathrm{~cm}$ was harvested from the left thigh (Fig. Ic). The flap vessels were anastomosed to the superior thyroidal artery and vein in an end-to-end manner. The donor site was closed with a split-thickness graft. This patient had the most extensive scalp defect among our cases, and almost half of the thigh was harvested as an anterolateral thigh flap without any problems in flap circulation. During the follow-up period, healing progressed without complication (Fig. Id). During the $4^{\text {th }}$ month postoperatively, the patient died of local recurrence and distant metastasis.

\section{Case 2}

A 56-year-old female patient was admitted to our clinic with a nonhealing ulcerated mass in her occipital area (Fig. 2a). On incisional biopsy, the mass was definitively identified as a malignant proliferating trichilemmal tumor. The lesion was excised with wide skin margins peripherally and deep margins down to and including the periosteum. The resultant defect was $12 \times 18 \mathrm{~cm}$ (Fig. 2b). An anterolateral thigh flap of $14 \times 20$ $\mathrm{cm}$ was harvested from the right thigh. The superior thyroidal artery and vein were used for anastomosis. The donor site was closed with a split-thickness skin graft. The healing process was uneventful (Fig. 2c). The patient was followed-up for I year, and no evidence of local or regional recurrence was observed.
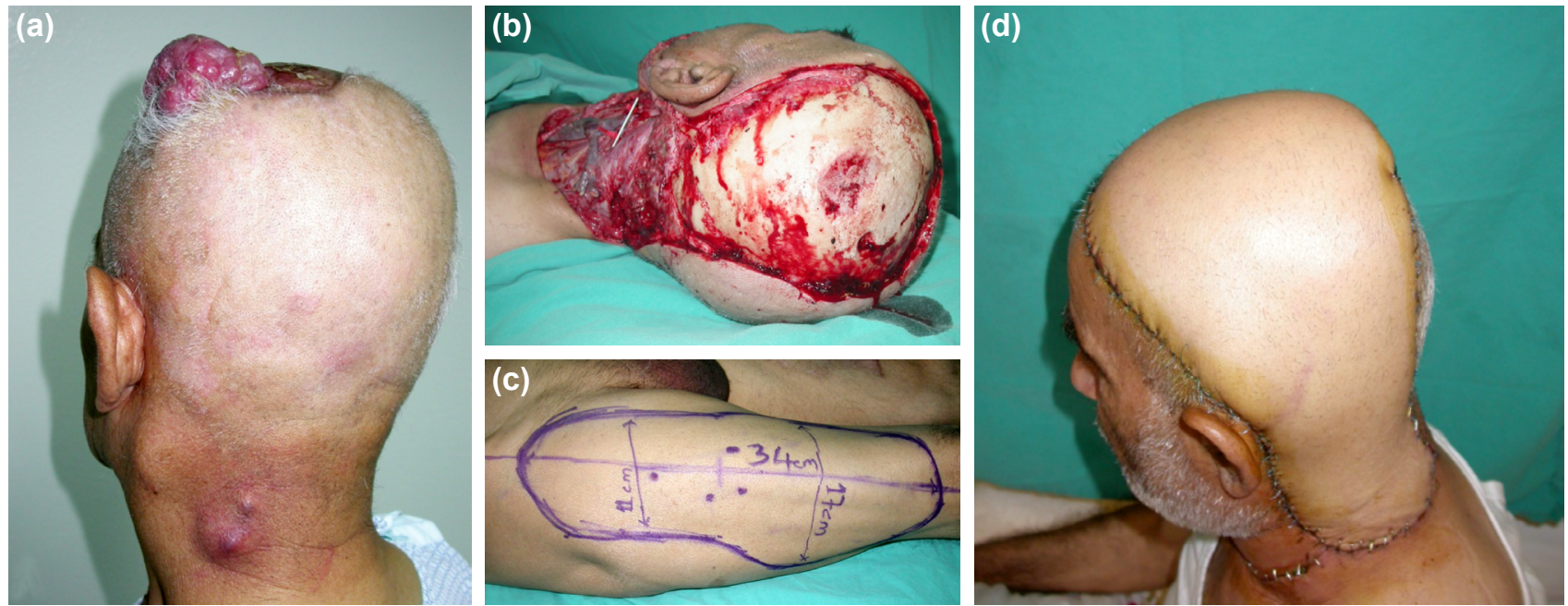

Figure 1. (a) Preoperative view of the scalp. (b) Scalp defect after excision. (c) Marking of the anterolateral thigh flap. (d) Final result at 15-day follow-up.
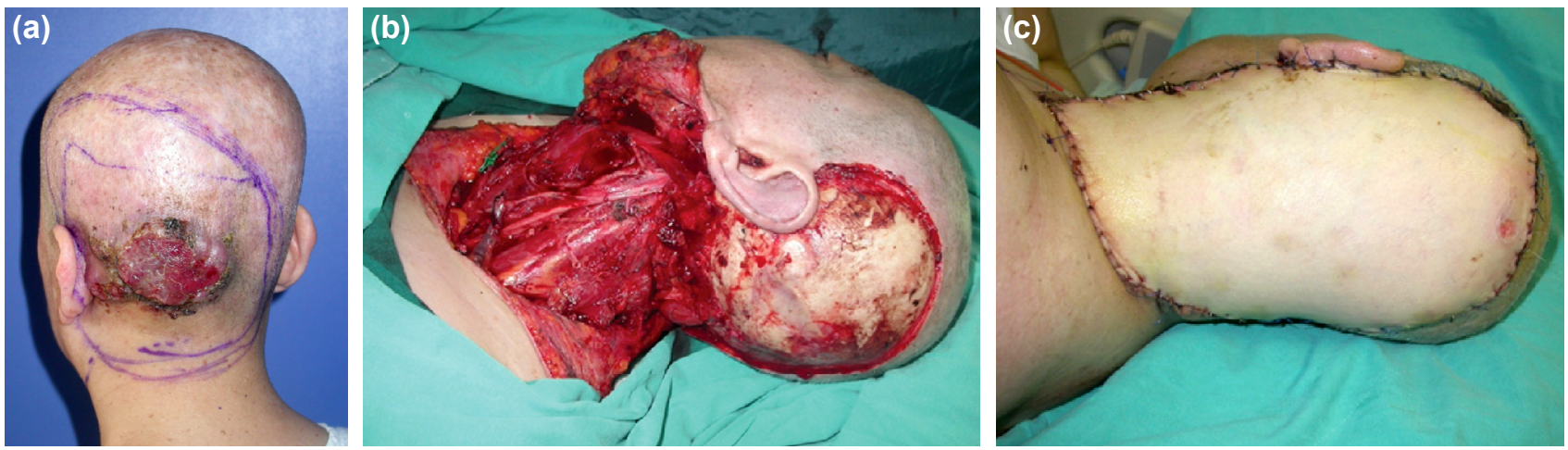

Figure 2. (a) Preoperative occipital view of a patient with an ulcerated mass on her scalp. (b) Defect after excision. (c) Postoperative view at 3-week follow-up showing the anterolateral thigh flap covering the entire defect. 


\section{DISCUSSION}

In scalp reconstruction, primary closure is the preferred treatment approach for small scalp defects, and secondary healing is less frequently preferred. For larger defects wherein primary closure is not an option, skin grafting is a reliable method for closing the wound if sufficient vascularized tissue is present. However, this approach has certain disadvantages for patients such as skin color variation, contour irregularities, and alopecia. ${ }^{[18]}$ Tissue expansion is a suitable option to avoid these disadvantages and reconstruct the scalp defect with hair-bearing tissue. Defects involving up to $50 \%$ of the total surface area of the scalp can be closed with this technique. ${ }^{[19]}$ However, tissue expansion is an elective process, and it requires stable calvarial coverage, patient compliance, and an adequate amount of scalp tissue. ${ }^{[20]}$

For patients who are not suitable candidates for tissue expansion, but need prompt wound closure, local flaps are a reliable option. These flaps are versatile and can be easily transposed, rotated, or advanced. Due to the inelastic property of the scalp tissue, only small- to moderate-sized uncomplicated scalp defects can be closed with local flaps. When the scalp tissue is not suitable for use as a local flap, regional flaps are the next option. The primary regional flaps used in scalp reconstruction are the latissimus dorsi, pectoralis major, trapezius, temporalis, and temporoparietal flaps. The major problem associated with the use of regional flaps is their limited arc of rotation; thus, regional flaps are only suitable for the closure of peripheral scalp defects.

Free-tissue transfer is the only surgical option if the defect size is too large and cannot be closed with locoregional flaps or if defects become complicated due to previous radiotherapy or unsuccessful surgical attempts.

The anterolateral thigh flap was first described in 1984 and was gradually popularized thereafter. ${ }^{[2]]}$ In this study, we used the anterolateral thigh free flap in all cases. The anterolateral thigh flap has a wide variability in size. It has been harvested as large as $33 \mathrm{~cm} \times 14 \mathrm{~cm}$ and is suitable for the reconstruction of extremely large or near-total scalp defects in one stage. ${ }^{[22]}$ Primary closure of the donor area can be utilized for up to $10-\mathrm{cm}$ wide flaps; grafting is required for larger flaps. The pedicle length is approximately $10-12 \mathrm{~cm}$ if the descendent branch is dissected where it emerges from the lateral circumflex artery and is sufficient to reach the ipsilateral neck for anastomosis without a vein graft. ${ }^{[23]}$ We used neck vessels in five patients, and anastomoses were performed without the need for a vein graft. The anterolateral thigh flap is useful due to the pliable nature of the anterolateral thigh skin. In overweight or obese patients, the subcutaneous tissue of the flap can be thinned with special attention to perforator localization. ${ }^{[24]}$ When harvested as a fasciocutaneous flap, none of the major arteries or muscles in the body is sacrificed. The vascularized vastus lateralis muscle or fascia lata can be simul- taneously harvested with the anterolateral thigh flap in cases of infection or dural defects to accelerate healing and prevent cerebrospinal fluid leakage. ${ }^{[25]}$

\section{Conclusion}

For extensive scalp defects, free-tissue transfer is the only option. The surgical aim for these types of scalp defects is closing the defect with reliable and durable soft tissue in one step. The anterolateral thigh flap is the only tissue flap that meets these criteria because of its variability in size and suitability for the reconstruction of major defects, malleability, long and reliable vascular pedicle, two-team approach to operation, and low donor site morbidity.

\section{Conflict of interest: None declared.}

\section{REFERENCES}

1. Lutz BS, Wei FC, Chen HC, Lin CH, Wei CY. Reconstruction of scalp defects with free flaps in 30 cases. Br J Plast Surg 1998;51:186-90.

2. Beasley NJ, Gilbert RW, Gullane PJ, Brown DH, Irish JC, Neligan PC. Scalp and forehead reconstruction using free revascularized tissue transfer. Arch Facial Plast Surg 2004;6:16-20. [CrossRef]

3. Lin PY, Miguel R, Chew KY, Kuo YR, Yang JC. The role of the anterolateral thigh flap in complex defects of the scalp and cranium. Microsurgery 2014;34:14-9. [CrossRef]

4. McLean DH, Buncke HJ Jr. Autotransplant of omentum to a large scalp defect, with microsurgical revascularization. Plast Reconstr Surg 1972;49:268-74. [CrossRef]

5. Hultman CS, Carlson GW, Losken A, Jones G, Culbertson J, Mackay G, et al. Utility of the omentum in the reconstruction of complex extraperitoneal wounds and defects: donor-site complications in 135 patients from 1975 to 2000. Ann Surg 2002;235:782-95. [CrossRef]

6. Furnas H, Lineaweaver WC, Alpert BS, Buncke HJ. Scalp reconstruction by microvascular free tissue transfer. Ann Plast Surg 1990;24:431-44.

7. Herrera F, Buntic R, Brooks D, Buncke G, Antony AK. Microvascular approach to scalp replantation and reconstruction: a thirty-six year experience. Microsurgery 2012;32:591-7. [CrossRef]

8. McCombe D, Donato R, Hofer SO, Morrison W. Free flaps in the treatment of locally advanced malignancy of the scalp and forehead. Ann Plast Surg 2002;48:600-6. [CrossRef]

9. Harii K, Yamada A, Ishihara K, Miki Y, Itoh M, May JW Jr. A free transfer of both latissimus dorsi and serratus anterior flaps with thoracodorsal vessel anastomoses. Plast Reconstr Surg 1982;70:620-9. [CrossRef]

10. Trignano E, Fallico N, Nitto A, Chen HC. The treatment of composite defect of bone and soft tissues with a combined latissimus dorsi and serratus anterior and rib free flap. Microsurgery 2013;33:173-183. [CrossRef]

11. Serra MP, Longhi P, Carminati M, Righi B, Robotti E. Microsurgical scalp and skull reconstruction using a combined flap composed of serratus anterior myo-osseous flap and latissimus dorsi myocutaneous flap. J Plast Reconstr Aesthet Surg 2007;60:1158-61. [CrossRef]

12. Mehrara BJ, Disa JJ, Pusic A. Scalp reconstruction. J Surg Oncol 2006;94:504-8. [CrossRef]

13. Oh SJ, Lee J, Cha J, Jeon MK, Koh SH, Chung CH. Free-flap reconstruction of the scalp: donor selection and outcome. J Craniofac Surg 2011;22:974-7. [CrossRef]

14. Dulin WA, Avila RA, Verheyden CN, Grossman L. Evaluation of abdominal wall strength after TRAM flap surgery. Plast Reconstr Surg 2004:113:1662-7. [CrossRef]

15. Kobienia BJ, Migliori M, Schubert W. Preexpanded radial forearm free flap to the scalp. Ann Plast Surg 1996;37:629-32. [CrossRef] 
16. Bo B, Qun Y, Zheming P, Haitao X, Tianyi L. Reconstruction scalp defects after malignant tumor resection with anterolateral thigh flaps. J Craniofac Surg 2011;22:2208-11. [CrossRef]

17. Fowler NM, Futran ND. Achievements in scalp reconstruction. Curr Opin Otolaryngol Head Neck Surg 2014;22:127-30. [CrossRef]

18. Tutela JP, Banta JC, Boyd TG, Kelishadi SS, Chowdhry S, Little JA. Scalp reconstruction: a review of the literature and a unique case of total craniectomy in an adult with osteomyelitis of the skull. Eplasty 2014;14: e27.

19. Manders EK, Schenden MJ, Furrey JA, Hetzler PT, Davis TS, Graham WP 3rd. Soft-tissue expansion: concepts and complications. Plast Reconstr Surg 1984;74:493-507. [CrossRef]

20. Lin SJ, Hanasono MM, Skoracki RJ. Scalp and calvarial reconstruction. Semin Plast Surg 2008;22:281-93. [CrossRef]

21. Song YG, Chen GZ, Song YL. The free thigh flap: a new free flap concept based on the septocutaneous artery. Br J Plast Surg 1984;37:149-59.

22. Kuo YR, Seng-Feng J, Kuo FM, Liu YT, Lai PW. Versatility of the free anterolateral thigh flap for reconstruction of soft-tissue defects: review of 140 cases. Ann Plast Surg 2002;48:161-6. [CrossRef]

23. Wei FC, Jain V, Celik N, Chen HC, Chuang DC, Lin CH. Have we found an ideal soft-tissue flap? An experience with 672 anterolateral thigh flaps. Plast Reconstr Surg 2002;109:2219-26. [CrossRef]

24. Cigna E, Minni A, Barbaro M, Attanasio G, Sorvillo V, Malzone G, et al. An experience on primary thinning and secondary debulking of anterolateral thigh flap in head and neck reconstruction. Eur Rev Med Pharmacol Sci 2012;16:1095-101.

25. Heller F, Hsu CM, Chuang CC, Wei KC, Wei FC. Anterolateral thigh fasciocutaneous flap for simultaneous reconstruction of refractory scalp and dural defects. Report of two cases. J Neurosurg 2004;100:1094-7.

\section{OLGU SERİSİ - ÖZET}

\section{Geniş saçlı deri defektlerinin serbest anterolateral uyluk flebi ile onarımı \\ Dr. Altuğ Altınkaya, ${ }^{1}$ Dr. Şükrü Yazar, ${ }^{1}$ Dr. İbrahim Sağlam, ${ }^{2}$ Dr. Kaan Gideroğlu ${ }^{3}$}

${ }^{1}$ Acıbadem Maslak Hastanesi, Plastik, Rekonstrüktif ve Estetik Cerrahi Anabilim Dalı, İstanbul

${ }^{2}$ Harran Üniversitesi, Araştırma ve Uygulama Hastanesi, Plastik, Rekonstrüktif ve Estetik Cerrahi Anabilim Dalı, Şanlıurfa

${ }^{3}$ Kartal Dr. Lütfi Kırdar Eğitim ve Araştırma Hastanesi, Plastik, Rekonstrüktif ve Estetik Cerrahi Kliniği, İstanbul

AMAÇ: Farkıı nedenlerle meydana gelen geniş saçlı deri defektlerinin onarımında çoğunlukla serbest doku nakilleri gerekmektedir. Bu çalışmanın amacı serbest anterolateral uyluk flebi ile onarım uygulanmış geniş saçlı deri defekti olan olgulardaki deneyimlerimizi gözden geçirmek ve paylaşmaktır.

GEREÇ VE YÖNTEM: 2007 ile 2015 yılları arasında geniş saçlı deri defekti olan, defekt onarımında anterolateral serbest uyluk flebi kullanılan olguların tıbbi kayıtları geriye dönük olarak tarandı. Ortalama yaşı 44 olan on bir hasta bu çalışmaya dahil edildi.

BULGULAR: Saçlı derideki geniş defekti onarmak için; genişliği 7 ile $14 \mathrm{~cm}$, uzunluğu ise 10 ile $34 \mathrm{~cm}$ arasında değişen on bir serbest anterolateral uyluk flebi kullanıldı. Hiçbir hastada flep kaybı gözlenmedi.

TARTIŞMA: Saçlı deri onarımında kullanılabilecek pek çok serbest flep seçeneği bulunmaktadır. Serbest anterolateral uyluk flebi diğer serbest flep seçeneklerine olan üstünlüğü, güvenilirliği ve avantajları nedeniyle geniş saçlı deri defekti olan olgularda ilk seçenek olarak değerlendirilebilir. Anahtar sözcükler: Anterolateral uyluk flebi; mikrocerrahi; saçlı deri; serbest flep.

Ulus Travma Acil Cerrahi Derg 2018;24(4):364-368 doi: 10.5505/tjtes.2018.94684 